\title{
How Does Financial Development Impact Trade Openness? Evidence from Export Performance of Pakistan
}

\author{
Muhammad Asif Shamim * $\quad$ Syed Tehseen Jawaid ${ }^{\dagger} \quad$ Farooq-e-Azam Cheema ${ }^{\ddagger}$
}

\begin{abstract}
Current Study examines the relationship between financial developments with export performance in Pakistan. This objective was attained by employing yearly time series method and statistics have been used from 1972 to 2014. This study develops financial development index by using principal component analysis. In addition to this, the effect of different ways of financial development has been analyzed, for instance market capitalization, domestic credit furnished by the financial sectors, credit to the private sectors, credit to the private sectors by banks and the ratio of money supply to GDP. Johansen and ARDL cointegration portrays a long-term link in all models. Since short-term relationships are concerned, error correction model has been put into service. The results assert that financial development indicators (FND, CFS, CPS, CPB, MKC and MNS) have an immense positive effects on export performance when it comes to short-run relationships. The result of FMOLS confirms that the introductory results are powerful. Stability analysis indicates that all the models are stable. Causality analysis validates that unidirectional causality is present from export to financial development in all the models. In the last section, a few policy recommendations and directions for the upcoming research are given.
\end{abstract}

Keywords: Export, financial development index, Pakistan.

\section{Introduction}

Capability of a nation to develop in economic terms and establish path way for people to work is strongly associated to the probability of exporting and probing into the external markets. Financial development is the determinant, which has the greatest significance, of field patterns and export volume. Countries that have better financial institutions specialize in industries which are financially intensive. Hence, they are able to export more. Exporting plays a vital role in providing entrance to a huge consumer market, obtain higher profits, increase work opportunities for the domestic individuals and enable firms to increase production. As a result, this can augment corporation production by permitting them to gain from economies of scale under obtainable manufacturing practices and finance in technology and innovation upgrading. The revelation to international know-how and the constant employment of imported goods in production for overseas nations can temporize productivity spillovers across the borders. Exports can also decline volatility over time

\footnotetext{
*Bahria University - Karachi Campus, Pakistan. E-mail: E-mail: asif_shamim19@hotmail.com

${ }^{\dagger}$ Applied Economics Research Centre, University of Karachi, Pakistan. E-mail: stjawaid@hotmail.com

‡Bahria University, Karachi Campus, Pakistan. E-mail: dr.cheema@live.com
} 
apart from growth rates and raising income levels. By exploring the international markets, exporters will be able to provide goods to the domestic markets and the international consumer markets. As a result, the seller of goods to another country may be in a position to hedge the ups and downs that are known as fluctuations in country-specific demands and insure which is against a decline at home and able to earn good returns.

There has been an escalating interest considering the character of the financial institutions in promoting not only the economic headway but also the financial improvement of the country. Literature supports that the growth of the financial market evolution is associated with the increase of goods that are being exported and services by using different types of methodologies. One of the basic explanations of financial sector of a country is that the financial institutions serve to reallocate funds from those who have excess amount of money and have given their opportunities in investments to those who are short of funds. Those countries where financial institutions have been well developed will be in a better position to dispense resources to projects that end up providing the highest returns. Theories of financial development suggest that it has important influence on the flow of international trade. Development of financial segment provides countries the comparative advantage in industries that depend on external finance. Financial institutions that are performing well are therefore extremely important to back up the worldwide exchange of goods and services.

The role of financial institutions in promoting exports was the focus of R. G. Rajan and Zingales (2003). They discovered that financial sectors with a greater need for finance made available to them externally develop proportionately faster in countries with more advanced financial markets. Wamboye and Mookerjee (2013) investigated the increasing export of 29 African manufacturing nations for the period of 16 years from 1995 to 2011 strive to encourage productivity and economic growth through diversification of export away from commodities. Financial development seeds manufactured export and manufactured export causes financial development in seven countries.

It can be stated that countries which have strong financial institutions eventually relish a comparative advantage \& export comparatively more in segments that are considered financially unsafe, but there isn't much information regarding the accurate mechanisms due to which abrasions caused by credits influences trade. First of all, institutions that aren't financially strong impede the growth and general economic activity. The international trade literature pays immense focus on factor endowments, technology and scale economies. These are the main focal points of the international trade literature when it comes to origins of comparative advantage, as a result factors of trade flows between the countries. There is a possibility of the extent of financial development to be a variable causing the structure of the trade balance. If that is the scenario, this has inferences for policy reforms in not only the financial but also in the sector of trade. On the one hand, an improvement of the sector pertaining to finance that increases the extent of finances present externally to companies in an economy may influence the structure of industries when considering the exports of this country. The flip side of the coin sheds light on the result of trade reforms on the industrial arrangement of the balance present in trade may be dependent on the level of finances obtainable externally in the economy.

Through various means, financial development can be put into good use of comparative 
advantage. Through one of the available channels, one sits on the constraints dependent on liquidity that quite a lot of firms have to deal with. Bearing in mind this stance, when a financial institution specifically a domestic one is not financially strong and not highly efficient, so firms in export-oriented sectors are crushed under the burden of highly important liquidity constraints that don't allow a Subdivision of productive business entities to launch in external market. If there is a possibility of firms to face credit constraints that are less limiting, for instance, the outcome of reforms in the financial sector, investment is the possible option to elevate more when responding to decreasing variable costs of exports and all firms with efficiency which is higher than a specific level become exporters. As a result, the main forecasts of theoretical papers shed light on the issue that development of financial sector should not only encourage production but also trade. There are few studies that have kept the index of financial development into consideration, but the study incorporates the index of financial development and different indicators of financial development for the disaggregate study so that analysis can be made on the consequence of those financial variables on the performance of export in Pakistan.

This research is better and improved from the previous studies on the basis of the following facts: financial development index has been constructed and used in the model. In addition to this, index and other estimates of financial development, namely domestic credit Furnished by sector of financial markets, credit to private sector, bank provided credit services to private sector, money supply and market capitalization. This study analyzes aggregate as well as disaggregate analysis of the financial development on the performance of export in Pakistan.

The following are the graphical representation of the variables used in this study such as CFS shows Domestic credit provided by financial sectors as \% of GDP, CPS shows Credit to private sector as \% of GDP, CPB shows Credit to private sector by banks as \% of GDP, MNS shows Ratio of money supply to GDP and MKC shows Market capitalization as \% of GDP. From graphical analysis, it is no easier to establish the relationship between financial development and export performance in Pakistan. It can only be clear up only by looking at the empirical evidence.

\section{Construction of Financial Development Index}

Pearson (1901) was the first person to invent the principal component method (PCM) and then Hotelling (1933) further amplified it. A technique that is multi variant is used by the PCM to figure out the relationships between a number of variables that are quantitative in nature. This method has been applied extensively on various areas, such as the calculation of environmental index (Kang, Kim, \& Lee, 2002). Not long ago, a simple globalization index was formulated by Agénor (2003) using PCM and then it was exercised on trade and financial openness. The principal components (PC) are arranged by descending order instead of ascending order of the Eigen values and they are the same as variance of the components. Method known as Eigen vectors is enumerated through unit length. The highest variance of any unit length that is linear fusion of determinant variables is in first component and similarly present for the last component. 
Figures 1 to 7
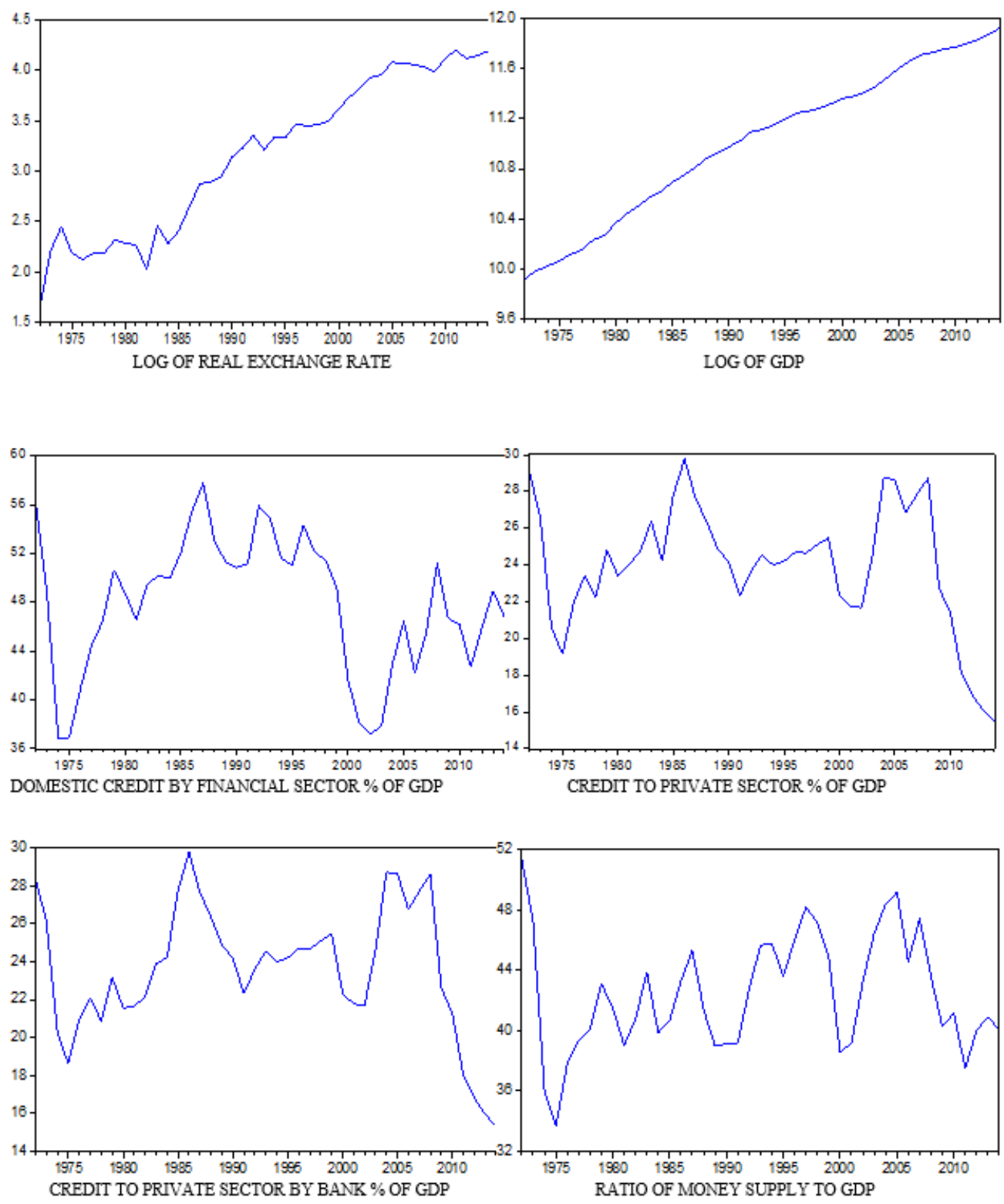


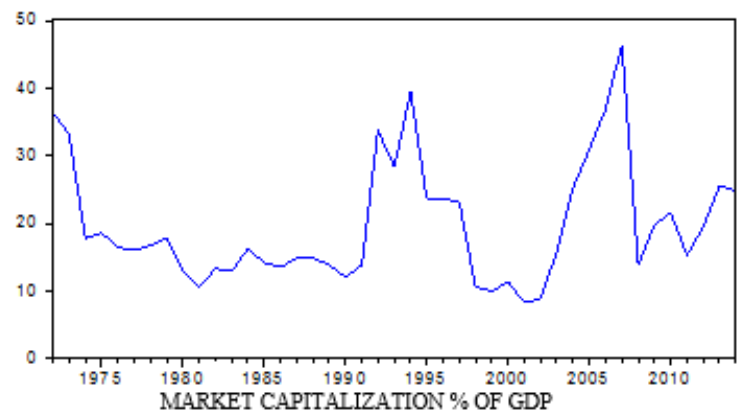

The ratio used for the financial development Index are Domestic credit furnished by financial sectors as \% of Gross Domestic Product (CFS), the Credit to private sector is taken as \% of Gross Domestic Product (CPS), Credit provided to private sector by banks as $\%$ of GDP (CPB), MNS shows Ratio of money supply to Gross Domestic Product (MNS) and Market capitalization as percentage of Gross Domestic Product (MKT).The weightage of each of the series is then enumerated by using the method known as principal component method $(\mathrm{PCM})^{1}$.

Financial Development Index Analysis

\begin{tabular}{|c|c|c|c|c|c|}
\hline \multicolumn{6}{|c|}{ Eigenvalues: $($ Sum $=5$, Average $=1)$} \\
\hline Number & Value & Difference & Proportion & Cumulative Value & Cumulative Value \\
\hline 1 & 2.974393 & 1.966439 & 0.5949 & 2.974393 & 0.5949 \\
\hline 2 & 1.007954 & 0.300153 & 0.2016 & 3.982347 & 0.7965 \\
\hline 3 & 0.707801 & 0.419761 & 0.1416 & 4.690148 & 0.9380 \\
\hline 4 & 0.288039 & 0.266226 & 0.0576 & 4.978187 & 0.9956 \\
\hline 5 & 0.021813 & - & 0.0044 & 5 & 1 \\
\hline \multicolumn{6}{|c|}{ Eigenvectors (loadings): } \\
\hline Variable & PC 1 & PC 2 & PC 3 & PC 4 & PC 5 \\
\hline CFS & 0.357536 & -0.127916 & 0.921950 & 0.075863 & -0.007626 \\
\hline CPS & 0.525016 & -0.319486 & -0.262547 & 0.248121 & 0.701279 \\
\hline CPB & 0.532732 & -0.273392 & -0.270744 & 0.247003 & -0.712138 \\
\hline MNS & 0.493922 & 0.272697 & -0.086044 & -0.821043 & 0.012738 \\
\hline $\mathrm{MKC}$ & 0.262227 & 0.855838 & -0.019282 & 0.444476 & 0.029102 \\
\hline \multicolumn{6}{|c|}{ Ordinary Correlations: } \\
\hline & CFS & CTPS & CTPSB & M2GDP & $\mathrm{MC}$ \\
\hline CFS & 1 & & & & \\
\hline CPS & 0.433502 & 1 & & & \\
\hline $\mathrm{CPB}$ & 0.430626 & 0.977028 & 1 & & \\
\hline MNS & 0.416012 & 0.641001 & 0.665378 & 1 & \\
\hline $\mathrm{MKC}$ & 0.165645 & 0.169686 & 0.214538 & 0.516551 & 1 \\
\hline
\end{tabular}

\footnotetext{
${ }^{1}$ Recently Jawaid and Waheed (2017) has used the same methodology.
} 


\section{Financial Development Index Analysis}

From the details given above, the first PC describes regarding $59.49 \%$, the second PC makes clear $20.16 \%$, the third and fourth PC $14.16 \%$ and $5.76 \%$ congruently, and the last prime component narrates $0.44 \%$ of the variance that is standardized. Thus, the first $\mathrm{PC}$ is used to estimate financial development index for Pakistan. The first PC is a linear combination of the five standardized measures of financial development with significance given by the eigenvector which is on the first position. After rescaling, the discrete contributions of each series CFS, CPS, CPB, MNS and MKC to the standardized variance of the first PC are following $35.75 \%, 52.50 \%, 53.27 \%, 49.39 \%$ and $26.22 \%$ respectively.

\section{Literature Review}

Many studies have figured out that financial development effects the economic outcomes of different countries. Studies conducted by two eminent researchers, (Levine, 1999; Levine, Loayza, \& Beck, 2000) revealed that a powerful relationship is present amongst the amount of financial development and growth. After sometime, the researches performed by R. G. Rajan and Zingales (2003); Beck (2002); Levine et al. (2000) signified the fact that it will be more convenient to obtain to finance available externally for projects that require investment given that the financial sectors are well established. The literature known as 'law matters' which was originated by La Porta, Lopez-de Silanes, and Shleifer (2002) and further inaugurated by Beck, Demirgüç-Kunt, and Levine (2003) recognized the association between development in the financial sector and the legal institutions. Not long ago, (Beck, 2003; Svaleryd \& Vlachos, 2005) demonstrated a constructive relationship amongst improvement in the financial sector and the structure of specialization in trade and comparative advantage.

Financial development has been recognized in the current studies where it served as a footing of comparative advantage in trade being done internationally, which was concluded by the eminent researchers, namely (Kletzer \& Bardhan, 1987; Demirgüç-Kunt \& Maksimovic, 1998; R. Rajan \& Zingales, 1998; Beck, 2002, 2003).

Rewilak (2017) probed whether financial development plays a vital role in reducing poverty, financial deepening and a higher physical access in decreasing number of people below the poverty line. A sample of those countries that were considered in the developing phase was taken over the period of 11 years from 2004 to 2015. Variables that were used GDP per Capita, Trade Openness, Inflation Rate, Government Spending, Economic Growth and Mobile Money. Base line model estimation has been employed. The result interprets that the two variables financial stability and Banking sector inefficiency don't have a detrimental effect on poverty reduction. Furthermore, it advocates that the financial instability and inefficiency have no direct harmful effect on poverty. It is recommended that declining poverty effects financial deepening and it might be elevated if it conflicts with enlarging the inclusiveness and accessibility of the financial sector.

Ohlan (2017) scrutinized the relationship amongst the two variables, namely economic growth and tourism in India by bearing in mind the significance of financial development over the period 1960?2014. Correlation technique has been employed in this research. The 
outcomes portray that the three variables, namely tourism, economic growth and financial development are co-integrated as the inward bound tourism spreads economic growth in the country, both in long-run and short-run. Addition to it, the examinations indicate presence which is speeding up from tourism to economic growth. Hence, strategies for alluring a greater number of international tourists should be encouraged.

Shahbaz, Van Hoang, Mahalik, and Roubaud (2017) examined the relationship amongst consumption of energy and economic growth by employing nonlinear multivariate ARDL bound tests methodology by using labor, financial development and capital under a production function cloaking economy of India since 1960-2015 and amalgamated data on real GDP, energy use, real domestic credit to the private sector, real gross fixed capital formation \& labor force computed by the proportion of the total population aged between 15 and 64. This technique can apprehend the non-linear and asymmetric co-integration amongst the variables. Results show that no vital causal relationship exists between labor force and economic growth in India. Shows that economic progress is achievable without investing a hefty amount in the labor force. Finally, it is recommended that people who are entitled with the responsibility to make policies in India should protect the rapidly growing and environment friendly escalation of the economy of India. This can be done by including technologies that not only save energy but also promote growth stimulation to the production function.

Chan and Manova (2015) swayed the choice of trade partners in different countries. They explored theoretically and factually that imperfections in financial markets influence the number and identity of destinations of exporters. Huge economies that have lesser trade costs are actually appealing as they provide export profits that are pleasing. It is suggested that countries should consider following the export destination hierarchy which is actually trade cost and the size of market etc.

Jaud, Kukenova, and Strieborny (2015) revealed financial development effects on longterm trade and also probed the requirements pertaining to finance at the product level by taking data of firm product export from five countries in the category of development phase. Cross sectional data is employed by using share of exporting country as exogenous variable and limited control as the endogenous variable. Results show that financial development assists disproportionately more "risky" products to persist. The outcomes agree with no doubt on literature available currently on finance and trade which are financially dependent on either industry or firm level.

Manova (2012) investigated that financial market imperfections which highly limit the flows of international trade as exporters are in dire need of capital to made available to them externally. The study included financial frictions into a heterogeneous-firm model and applied it to cluster data available on trade for a good number of countries' bilateral trade, 27 industries from 1985 to 1995 . Results portray that frictions in the availability of finance hinder selection of firms into production, the entry of producers into exporting and foreign sales of exporters. Therefore, it is recommended that such policy may be formulated keeping in view potential consequences.

Adnan Hye and Islam (2013) empirically reviewed longrun and short-run relationship between financial development and economic growth by formulating the first FDI that is financial development index for the country Bangladesh by employing principle components 
methods. The study used FDI and RIR as an exogenous variable while export was used as an endogenous variable to inspect the presence of a relationship that will exist in the long-run amongst economic growth and FDI. The two tests, namely the Ng-Perron unit root test and Augmented Dickey Fuller have been employed to scrutinize the stationarity properties of the series. A long-run relation has been figured out by ARDL also known as the Autoregressive Distributed Lag approach to co-integration. The rolling window regression technique has been incorporated to test stability of parameters. Results portray that the effect of Real Interest Rate and Foreign Direct Investment on economic growth is bleak. The calculations from the rolling window method portray that not only real interest rate but foreign direct investment is also not positively related to economic growth. Shamim, Khan, Ghais, and Shaikh (2016) also found the positive relationship between foreign direct investment and exports in Pakistan.

Alvarez and López (2013) examined the consequence that financial development has on the chance of exporting at the plant level with a special focal point on the diverse responses of plants with contrasting characteristics by sing a linear probability model on Chilean manufacturing plants for the period defined as 1990-2000. That permitted to control for plant that are unobserved and vary in time when it comes to industries that are diverse. It has been noticed that financial development has a constructive effect on the chances of exporting of more plants that are productive and also those plants that are owned by foreigners. It can be said that they function in sectors that rely heavily on finances available externally. The large plants are more advantageous than the smaller and younger plants.

Kiendrebeogo (2012) inspected that the countries recognized with financial systems that are said to be developed better tend to be specialists in those industries that are dependent on finances available externally in the sector of production. It has been observed that this effect has a greater probability to be witnessed in those countries that have high grade institutions. In this study, cross-sectional and panel specifications have been employed on 75 countries over the period 1971-2010. Regression analysis as a statistical technique has been applied for reaching to a result.

Vera (2010) investigated the consequence of the financial system development of a country when considering a firm's percentage of sales in exports bearing in mind the financial vulnerability of an industry. The simplest model is composed of two open economies, inhabited by the land owners and a continuum of identical entrepreneurs; a single good created with constant return to scale technology and using physical capital and land has been employed.

Susanto, Rosson III, and Costa (2011) empirically explored outcome of financial growth not only on trade of but also on agriculture products and products that are being manufactured. An indicator of financial reforms that measure financial measure or liberalization has been employed. An annual export data for a sample of forty nine countries for the period of 1980 to 2008 has been kept into consideration. Results show a constructive effect of financial development on mutual trade flows for the manufacturing sector with comparatively big economies of scale and minor impact for agriculture. Outcomes can prove to be very helpful as it can be applied to those economies where economic growth, financial development and trade has to be triggered. 
Berthou et al. (2010) explored the crooked effects of financial development on the margins that are both intensive and extensive of the exports of two countries or the International Trade, at different levels of economic development. The data is gathered from 50 countries that are involved in exports, 85 countries that are occupied in imports and 26 industries that lie in the domain of ISIC for the years 1990 to 2000. The empirical examination assert that financial development motivates the intensive and extensive margins of the exports of countries.

Samba and Yan (2009) inspected the association amongst the degree of financial development of a specific country and its relative advantage in global trade. To assess the long-term relationship between the variables such as financial development and international trade in manufactured goods, a VAR Model along with a time-series approach has been employed. The result suggested that for majority countries, financial development is augmented by trade across countries in manufactured goods

Hur, Raj, and Riyanto (2006) inspected the interaction between financial development, asset tangibility on exports by keeping into consideration the level of industrial data on dependence of firms on finance available externally and asset tangibility of firms for 52 countries and 23 industries. It was inferred that economies that have greater level of financial development end up with higher export portions in industries that use greater intangible assets and the impact was augmented in the external finance dependence of the industry. Moreover, there is a constructive significant relationship amongst property right protection and export share in industries that have more intangible assets. He further highlighted the interplay amongst asset tangibility, financial development, and exports by using industry level data on dependence of firms on finance available externally and asset tangibility of firms for 52 countries and 23 industries. It was inferred that economies with a greater degree of financial development have greater portions of export in those industries that are equipped with more intangible assets and the influence is said to be augmenting in those industries that are at the mercy of finance available externally.

Beck (2002) discovered a relationship that maybe possible between financial development and trade in manufactures by employing a sample consisting data for 65 countries and 30 years panel data from the years 1966 and 1995. The investigation is constructed on the work done by Kletzer and Bardhan in the year 1987. The results of the study show that the degree of financial development has a huge influence on the stage of export and the balance of trade achieved in manufactured goods. Countries with lower degree of financial development can opt for reforms that increase the availability of external finance to the private sector. Hence, this is the best implication of this study.

From the above literature review we cannot come up with a concrete conclusion on the association between financial development and export in Pakistan. Therefore, the current study examines how financial development impact exports performance in Pakistan with new data set and more rigorous econometrics techniques. 


\section{Methodology}

After reviewing the theoretical and empirical studies, export function is used to examine outcome of financial development and export performance in Pakistan. Below are the export functions with different measures of financial development with aggregate and disaggregate level ${ }^{2}$ :

$$
\begin{aligned}
& E X P_{t}=\alpha_{0}+\alpha_{1} G D P_{t}+\alpha_{2} R E R_{t}+\alpha_{3} F N D_{t}+\epsilon_{t} \\
& E X P_{t}=\beta_{0}+\beta_{1} G D P_{t}+\beta_{2} R E R_{t}+\beta_{3} C F S_{t}+\zeta_{t} \\
& E X P_{t}=\chi_{0}+\chi_{1} G D P_{t}+\chi_{2} R E R_{t}+\chi_{3} C F S_{t}+\psi_{t} \\
& E X P_{t}=\gamma_{0}+\gamma_{1} G D P_{t}+\gamma_{2} R E R_{t}+\gamma_{3} C F B_{t}+\omega_{t} \\
& E X P_{t}=\delta_{0}+\delta_{1} G D P_{t}+\delta_{2} R E R_{t}+\delta_{3} M N S_{t}+\nu_{t} \\
& E X P_{t}=\varphi_{0}+\varphi_{1} G D P_{t}+\varphi_{2} R E R_{t}+\varphi_{3} M K C_{t}+\tau_{t}
\end{aligned}
$$

Where EXP is real exports, GDP is real gross domestic production, RER is real exchange rate and FND is financial development index erected by principal component analysis, CFS is domestic credit provided by financial sectors as percentage of GDP, CPS is credit provided to private sector as percentage of GDP, CPB is credit provided to private sector by banks as percentage of GDP, MNS is ratio of money supply to GDP and MKC is Market capitalization as percentage of GDP and $\epsilon_{t}, \zeta_{t}, \psi_{t}, \omega_{t}, \nu_{t}$ and $\tau_{t}$ are the error terms. Annual data have been taken from 1972 to 2014.

For stationary properties, Augmented Dickey Fuller and Phillips Perron test have been employed for the long-run relationship of time series variable. Johansen and ARDL cointegration are applied to figure out long-run relationship amongst export and financial development ${ }^{3}$.

In this study, two co-integration methods have been used, namely Johansen and Juselius (1990) co-integration methods and autoregressive distributed lag (ARDL). These two methods have been employed to investigate the long-run relationship amongst export and financial development in Pakistan. The ARDL method is quite better than the other cointegration techniques because it can be applied regardless of whether underlying variables are either purely $\mathrm{I}(0), \mathrm{I}(1)$, or mutually co-integrated. Moreover, it estimates small sample properties that are better, as a result the approximation of outcomes is possible even if the explanatory variables are endogenous.

The error correction model has been employed for short-term relationship. On the other hand, FMOLS has been used for the sturdiness of relationship that is long-term. Stability

\footnotetext{
${ }^{2}$ Jawaid, Raza, Mustafa, and Karim (2016) has also employed export function to find the effect of foreign direct investment on exports in Pakistan.

3 Jawaid and Waheed (2018) and have used the same methodology.
} 
of models has been checked through cumulative sum (CUSUM) and cumulative sum of square (CUSUMQ) test. Data for this study has been collected from either the website of World Bank, Pakistan economic survey (different various) and handbook of statistics of Pakistan economy.

\section{Estimation and Results}

The stationary properties in the series have been tested through the unit root test. Existence of structural changes in the series, unit root test was carried out by employing Phillips and Perron methodology and Dickey and Fuller statistics. Table 1 shows examination of stationary test. Augmented Dickey Fuller (ADF) test revealed that at level the variables are non-stationary and at the first difference the variables are stationary, which confirms that Johansen Co-integration test evident in table 2 is valid to figure out the long-run relationship while the PP-test statistics shows that rare variables are stationary at level. Therefore to justify the long run association between variables, the ARDL experiment has been carried out which is mentioned table 3 .

Johansen and Juselius (1990) co-integration procedure is incorporated to examine the long-run connection between the variables. Maximum Eigen value statistics and Trace Statistics are the two tests that have been obtained for co-integration. In the table, the calculated trace, their parallel critical values and Maximum Eigen Values statistics have been presented. The null-hypothesis states that no co-integration between the variables presented in the above models. Moreover, Trace and Maximum Eigen Value test statistics which are mentioned in table 2 indicate that the null hypothesis that has no co-integration has been rejected. Therefore, the outcomes of the two test statistics propose that there exists a established long term association of export and its prime components as expressed in the models are FND, CFS, CPS, CPB, MNS and MKC.

Persan and Pesaran (1997) developed the ARDL method of co-integration. The ARDL is more suitable than the other co-integration techniques. SBC also known as Schwarz Bayesian Criteria has been applied to recognize the optimum lag of the model in each series. Researcher first estimated F-statistics value by using the suitable ARDL model. Furthermore, Wald F-statistics test is employed to explore the long-term link among the series. Null hypothesis in which there is no co-integration is dismissed if the computed Ftest statistics is greater than the upper critical bound value. The outcomes are indecisive given that F-test statistics lie between the upper critical bound and the lower critical bound. Last but not least, our null hypothesis which has no co-integration is welcomed given that F-statistics is lesser the lower critical bound.

Outcome of all financial development models are given in table 3. The results show that no co-integration is present in the null hypothesis. Hence, it has been dismissed since the value of F-statistics is higher than the critical value of upper bound where level of significance is $1 \%$. This shows that long run link exists amongst EXP and other financial development indicators, namely FND, CFS, CPS, CPB, MKC and MNS.

Table 4 revealed that the long run determinants of the variables EXP , FND, CFS, CPS, CPB, MKC and MNS having expected and significant in all the models of financial 
developments.

FND, CFS, CPS, CPB, MKC and MNS have an effect on exports that is not only positive but significant as well. Therefore, an improvement in financial developments will surely result in an escalation in exports of Pakistan. The value of DW indicates that there is a chance of autocorrelation, therefore, HAC test is applied to overcome this problem ${ }^{4}$.

Table 1

Stationary Test Results

\begin{tabular}{lcccccccc}
\hline Variables & \multicolumn{2}{c}{ Augmented Dickey-Fuller Test } & \multicolumn{4}{c}{ Phillips-Perron Test } \\
\hline & \multicolumn{2}{c}{$\mathbf{I}(\mathbf{0})$} & \multicolumn{2}{c}{$\mathbf{I}(\mathbf{1})$} & \multicolumn{2}{c}{$\mathbf{I}(\mathbf{0})$} & $\mathbf{I}(\mathbf{1})$ & \\
& C & C\&T & C & C\& & C & C\& & C & C\& T \\
\hline FND & 0.142 & 0.457 & 0.000 & 0.001 & 0.014 & 0.061 & 0.000 & 0.002 \\
EXP & 0.782 & 0.639 & 0.000 & 0.000 & 0.782 & 0.557 & 0.000 & 0.000 \\
GDP & 0.380 & 0.931 & 0.001 & 0.003 & 0.145 & 0.939 & 0.001 & 0.003 \\
RER & 0.533 & 0.128 & 0.000 & 0.000 & 0.504 & 0.106 & 0.000 & 0.000 \\
MKC & 0.177 & 0.111 & 0.000 & 0.000 & 0.010 & 0.031 & 0.000 & 0.000 \\
CFS & 0.177 & 0.124 & 0.000 & 0.000 & 0.067 & 0.231 & 0.000 & 0.001 \\
CPS & 0.203 & 0.421 & 0.000 & 0.001 & 0.249 & 0.490 & 0.000 & 0.001 \\
CPB & 0.157 & 0.412 & 0.000 & 0.002 & 0.262 & 0.555 & 0.000 & 0.002 \\
MNC & 0.171 & 0.180 & 0.000 & 0.000 & 1.000 & 1.000 & 0.000 & 0.001 \\
\hline
\end{tabular}

Source: Authors' Estimation

Note: p-Values are given in Table 1

Table 2

Co-integration Test-Results

\begin{tabular}{lccccc}
\hline Model & $\begin{array}{l}\text { Hypothesis } \\
\text { No. of CE(s) }\end{array}$ & Trace statistics & $\mathbf{5 \%}$ critical values & $\begin{array}{c}\text { Max. Eigen } \\
\text { value statistics }\end{array}$ & $\mathbf{5 \%}$ critical values \\
\hline FND & None & 55.81 & 55.24 & 31.83 & 30.81 \\
& At Most 1 & 23.98 & 35.01 & 15.91 & 24.25 \\
& At Most 2 & 8.072 & 18.39 & 6.189 & 17.14 \\
& At Most 3 & 1.883 & 3.841 & 1.883 & 3.841 \\
\hline CFS & None & 91.73 & 63.87 & 34.95 & 32.11 \\
& At Most 1 & 56.78 & 42.91 & 32.87 & 25.82 \\
& At Most 2 & 23.91 & 25.87 & 16.63 & 19.38 \\
& At Most 3 & 7.279 & 12.51 & 7.279 & 12.51 \\
\hline CPS & None & 44.13 & 40.17 & 25.57 & 24.15 \\
& At Most 1 & 18.56 & 24.27 & 12.01 & 17.79 \\
& At Most 2 & 6.542 & 12.32 & 5.385 & 4.130 \\
\hline CPB & At Most 3 & 1.158 & 4.13 & 1.158 & 24.15 \\
& None & 46.70 & 40.17 & 26.06 & 17.79 \\
& At Most 1 & 20.63 & 24.27 & 12.24 & 11.22 \\
& At Most 2 & 8.390 & 12.32 & 7.191 & 4.130 \\
\hline MNS & At Most 3 & 1.200 & 4.130 & 1.200 & 27.58 \\
& None & 69.66 & 47.85 & 42.22 & 14.13 \\
& At Most 1 & 27.44 & 29.79 & 17.46 & 3.841 \\
\hline At Most 2 & 9.971 & 15.49 & 8.067 & 24.15 \\
\hline AKC & At Most 3 & 1.904 & 3.841 & 1.904 & 17.79 \\
& None & 54.36 & 40.17 & 24.64 & 11.22 \\
& At Most 1 & 29.71 & 24.27 & 18.17 & 4.130 \\
\hline At Most 2 & 11.54 & 12.32 & 10.94 & \\
\hline At Most 3 & 0.602 & 4.130 & 0.602 & \\
\hline
\end{tabular}

Source: Authors Estimation

\footnotetext{
${ }^{4}$ Gujarati (2007); Jawaid and Waheed (2018) have adopted the same methodology.
} 


\section{Test for Robustness}

In order to analyze the sensitivity of the model, FMOLS method is used. This technique, established by Phillips and Perron (1988), is used to scrutinize the vigorousness of primary results. This method also provides the optimum assessment of co-integration equation. One more advantage of this method is that it modifies OLS so that the serial correlation problem and endogeniety can be controlled in the regressors that upshot due to the presence of link in co-integration. Results are given in table 5.The outcomes of FMOLS revealed that the coefficient financial development FND, CFS, CPS, CPB, MKC and MNS are vital and are identical to ordinary least square (OLS), therefore, it can be concluded without any doubt that the outcomes from OLS are vigorous ${ }^{5}$.

Table 3

Lag Length Selection and ARDL Bound Testing for Cointegration

\begin{tabular}{|c|c|c|c|c|}
\hline Model & Lags Order & AIC & SBC & F-test Statistics \\
\hline \multirow{4}{*}{ FND } & 0 & 5.530 & 5.701 & \multirow{4}{*}{$11.51^{*}$} \\
\hline & 1 & $-2.800^{*}$ & $-1.955^{*}$ & \\
\hline & 2 & -2.510 & -0.990 & \\
\hline & 3 & -2.390 & -0.197 & \\
\hline \multirow[t]{4}{*}{ CFS } & 0 & 4.960 & 5.127 & \multirow{4}{*}{$16.18^{*}$} \\
\hline & 1 & $-3.407 *$ & $-2.562^{*}$ & \\
\hline & 2 & -3.030 & -1.512 & \\
\hline & 3 & -2.670 & -0.479 & \\
\hline \multirow[t]{4}{*}{ CPS } & 0 & 4.230 & 4.401 & \multirow{4}{*}{$21.15^{*}$} \\
\hline & 1 & $-4.282^{*}$ & $-3.438^{*}$ & \\
\hline & 2 & -4.070 & -2.554 & \\
\hline & 3 & -3.910 & -1.714 & \\
\hline \multirow[t]{4}{*}{$\mathrm{CPB}$} & 0 & 4.320 & 4.488 & \multirow{4}{*}{$14.79^{*}$} \\
\hline & 1 & $-4.307 *$ & $-3.463^{*}$ & \\
\hline & 2 & -4.100 & -2.576 & \\
\hline & 3 & -3.910 & -1.716 & \\
\hline \multirow[t]{4}{*}{ MNS } & 0 & 30.42 & 30.59 & \multirow{4}{*}{$11.54^{*}$} \\
\hline & 1 & $17.45^{*}$ & $18.30^{*}$ & \\
\hline & 2 & 17.70 & 19.21 & \\
\hline & 3 & 17.75 & 19.95 & \\
\hline \multirow[t]{4}{*}{ MKC } & 0 & 5.960 & 6.133 & \multirow{4}{*}{$12.12^{*}$} \\
\hline & 1 & $-1.784^{*}$ & $-0.939^{*}$ & \\
\hline & 2 & -1.430 & 0.091 & \\
\hline & 3 & -1.210 & 0.990 & \\
\hline
\end{tabular}

\section{Test for Short-run Relationship}

To inspect the short-term link, modeling approach where two lag of endogenous, one lag of exogenous variables and one lag of error correction term were included in the model. Ideal model is stated in Table 6 after examining universal form of the error correction model ${ }^{6}$.

Results assert that Financial Development indicators (FND, CFS, CPS, CPB, MKC and MNS) have an effect on export that is significant and positively affect the short-run.

\footnotetext{
${ }^{5}$ Also seen Jawaid and Saleem (2017); Jawaid (2014).

${ }^{6}$ Hendry (1980).
} 


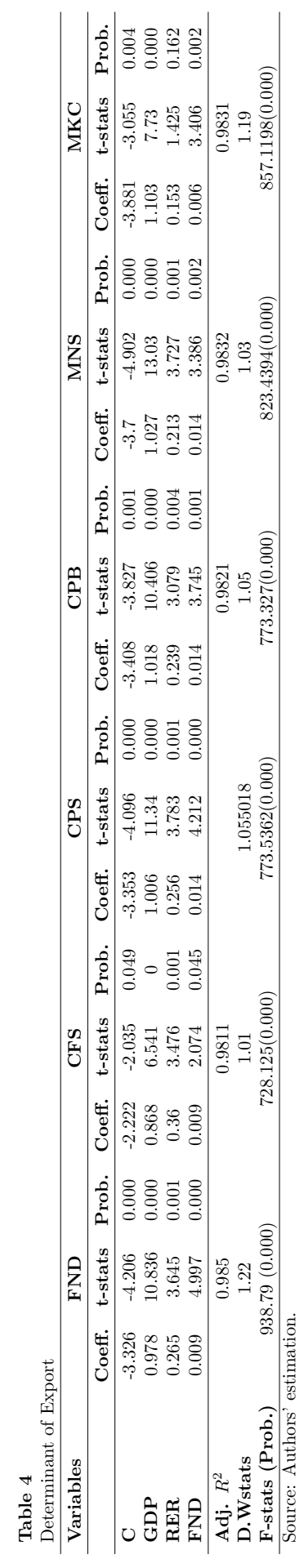




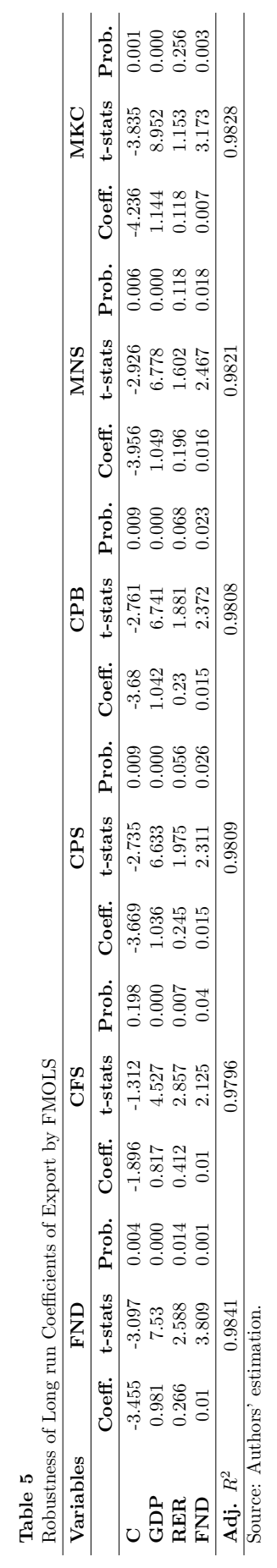




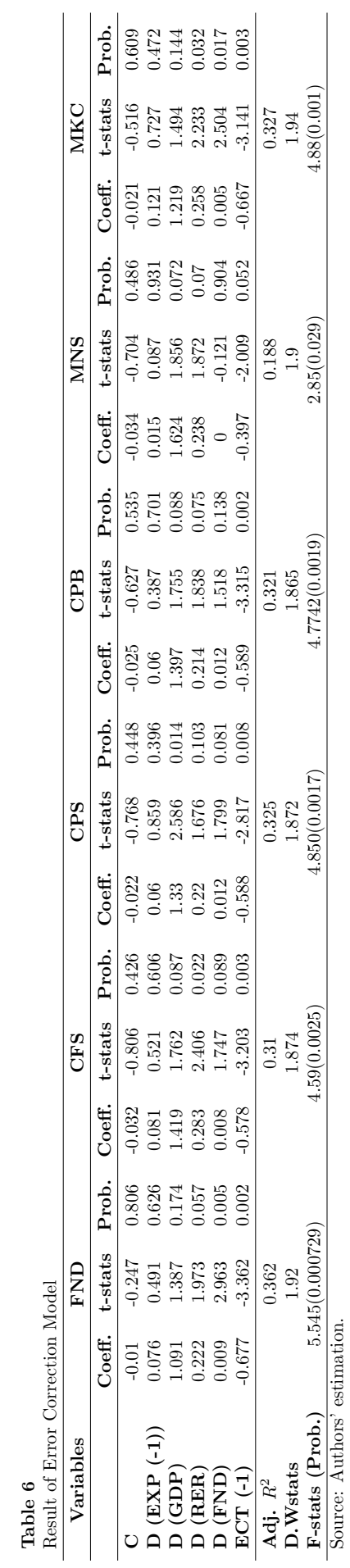


There is expected negative sign in the error terms coefficient and is truly important. The high value present in the error terms coefficient proposes that this model coincides rapidly to the balance value.

\section{Figures 8 to 13}

Plot of cumulative sum of recursive residuals. The straight lines represent critical bounds at $5 \%$ significance level.
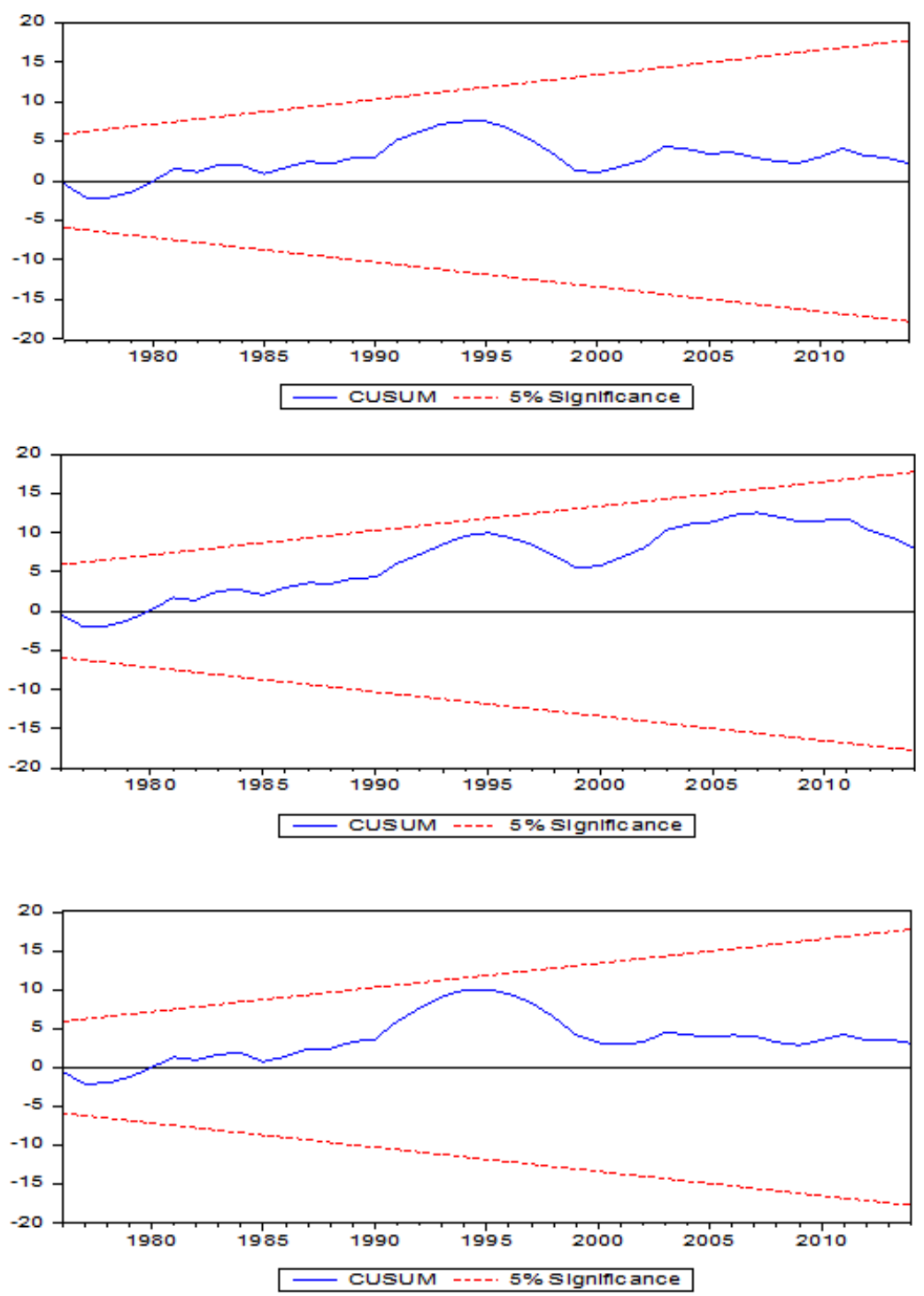

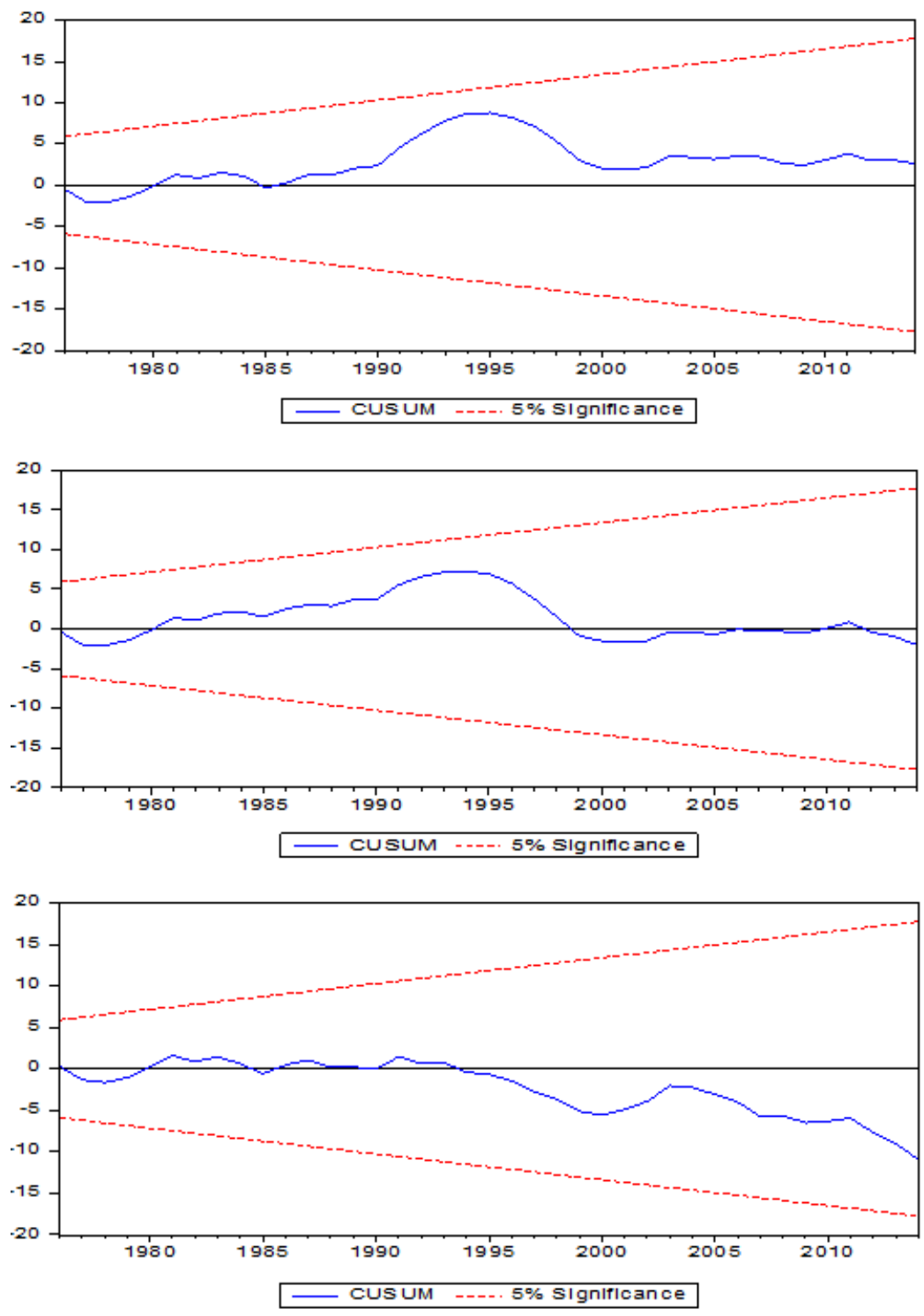


\section{Figures 14 to 19}

Plot of cumulative sum of squares of recursive residuals. The straight lines represent critical bounds at $5 \%$ significance level.
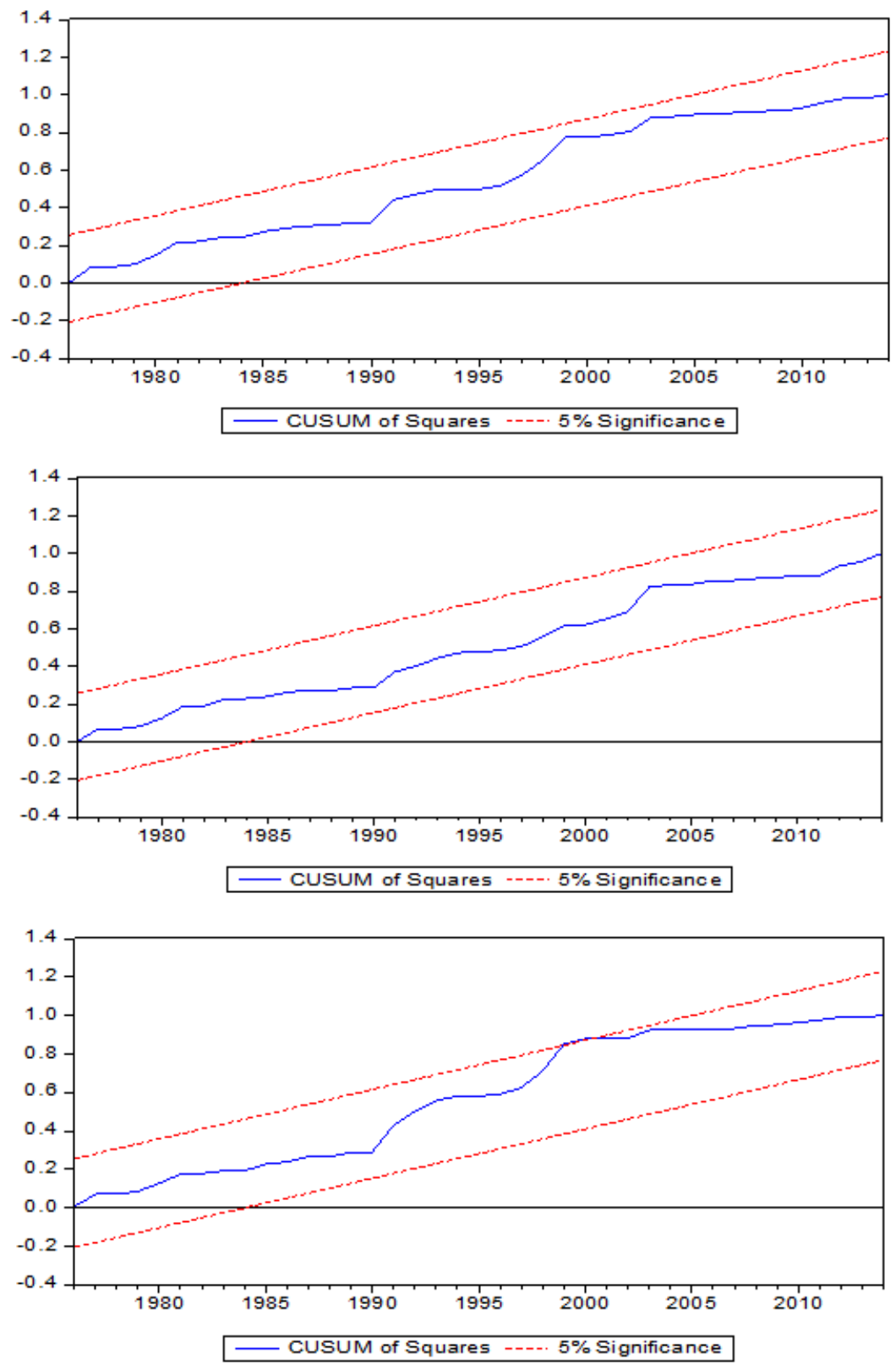

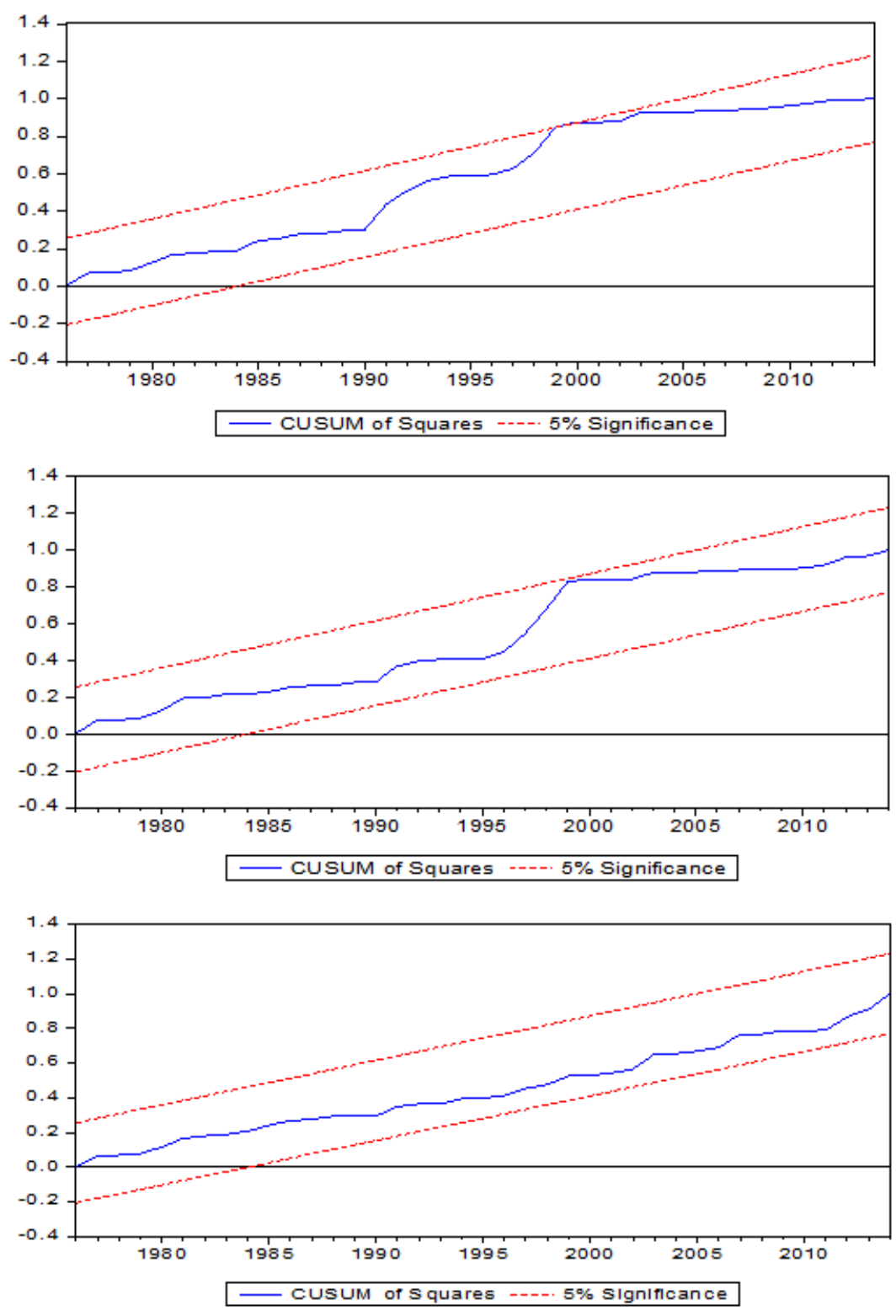

\section{Stability Analysis}

The stability of long-term estimates is assessed by using CUSUM and CUSUMQ tests on the recursive residuals. It has been noticed that CUSUMQ test is in a position to recognize unexpected variability which has arisen from constancy of regression coefficient. On the 
other hand, the orderly changes from the coefficient of regression are discerned through CUSUM test.

CUSUM test shows that coefficients are statistic throughout the sample period. On the other hand, figures 14 to 19 CUSUM of square suggest that coefficients are also firm throughout the sample period ${ }^{7}$.

\section{Conclusion and Policy Recommendations}

This study examines the relationship between financial development and export performance in Pakistan. The export function is employed to check the influence of financial development on export by using yearly time series data are used from 1972 to 2014. More rigorous econometric techniques are applied in this study which includes ARDL approach to co-integration, Johansen co-integration for long run relationship. FMOLS has been applied to check the robustness of the initial results and error correction model are used to find short run relationship. Significant positive long-term relationships among exports and financial development have been suggested in long run. All measures of financial development have significant positive effect on export in short run except CPB and MNS in short run. Sensitivity analysis confirms that the initial results are robust.

Policy makers should pay heed to export promotion strategy so the financial development in Pakistan can be intensified. Due to the inadequacy of knowledge about how to effectively build your market abroad, the developing countries that have newly emerged were not in a position to augment their exports themselves. Although they've advanced technology and they take complete advantage of widespread use of digital mobile devices, marketing outside the border is quite challenging for most small businesses in any country.

Governments usually take charge and help out small businesses to encourage exports in a number of ways. One of the steps can be helping them elevate the sales of products that are currently available for export. This is called export promotion. Most governments consider export promotion and development as a priority because it assists them in achieving certain economic development goals. There are various policies to encourage exports of any country but financial development is the main factor for promoting it. Government should especially make policies to promote credit to the private sector. Also, credit to the private sector by banks and money supply can be encouraged in order to escalate export in Pakistan.

It is observed that negative shock in financial development affect the export performance in the country and economic growth. In order to enhance export earning, government should encourage the productive loan and discourage the non-performance loan. Government has to evaluate the credit worthiness of the public and private sector before the issuance of the loan. Unrealistic practices of lending adversely affect Pakistan's macroeconomic performance as a whole specially hurt the export performance. Overall, financial development is exclusively significant for long-term export existence if target markets are of both developed and developing countries.

\footnotetext{
${ }^{7}$ Chow breakpoint test confirm that there is no structural break in figure 16,17 and 18.
} 
It is suggested that monetary policy commission in Pakistan should provide instruction to both sectors including public \& scheduled commercials banks to proceed the distribution of credit to productive sectors and this can be done by stricting credit provisioning policies for nonproductive loans that they sanctioned in the economy. It is also recommended that authorities that are entitled to make policies in Pakistan should meticulously verify the proper allotment of financial resources provided to various competing consumptions and also the business activities in order to reduce the ramifications of export performance. 


\section{References}

Adnan Hye, Q. M., \& Islam, F. (2013). Does financial development hamper economic growth: Empirical evidence from Bangladesh. Journal of Business Economics and Management, 14(3), 558-582.

Agénor, P.-R. (2003). Does globalization hurt the poor? World Bank. Unpublished manuscript.

Alvarez, R., \& López, R. A. (2013). Financial development, exporting and firm heterogeneity in chile. Review of World Economics, 149(1), 183-207.

Beck, T. (2002). Financial development and international trade: Is there a link? Journal of International Economics, 57(1), 107-131.

Beck, T. (2003). Financial dependence and international trade review of international economics.

Beck, T., Demirgüç-Kunt, A., \& Levine, R. (2003). Law, endowments, and finance. Journal of financial Economics, 70(2), 137-181.

Berthou, A., et al. (2010). The distorted effect of financial development on international trade flows (Tech. Rep.).

Chan, J. M., \& Manova, K. (2015). Financial development and the choice of trade partners. Journal of Development Economics, 116, 122-145.

Demirgüç-Kunt, A., \& Maksimovic, V. (1998). Law, finance, and firm growth. The Journal of Finance, 53(6), 2107-2137.

Gujarati, D. N. (2007). Sangeetha (2007) basic econometrics. Tata McGraw Hill Publishing Company Limited, New Delhi, 110(8), 451-452.

Hendry, D. F. (1980). Econometrics-alchemy or science? Economica, 387-406.

Hotelling, H. (1933). Analysis of a complex of statistical variables into principal components. Journal of Educational Psychology, 24(6), 417-444.

Hur, J., Raj, M., \& Riyanto, Y. E. (2006). Finance and trade: A cross-country empirical analysis on the impact of financial development and asset tangibility on international trade. World Development, 34(10), 1728-1741.

Jaud, M., Kukenova, M., \& Strieborny, M. (2015). Financial development and sustainable exports: Evidence from firm-product data. The World Economy, 38(7), 1090-1114.

Jawaid, S. T. (2014). Trade openness and economic growth: A lesson from Pakistan. Foreign Trade Review, 49(2), 193-212.

Jawaid, S. T., Raza, S. A., Mustafa, K., \& Karim, M. Z. A. (2016). Does inward foreign direct investment lead export performance in Pakistan? Global Business Review, $17(6), 1296-1313$.

Jawaid, S. T., \& Saleem, S. M. (2017). Foreign capital inflows and economic growth of pakistan. Journal of Transnational Management, 22(2), 121-149.

Jawaid, S. T., \& Waheed, A. (2017). Contribution of international trade in human development of Pakistan. Global Business Review, 18(5), 1155-1177.

Jawaid, S. T., \& Waheed, A. (2018). A macroeconometric model for trade policy evaluation: Evidence from Pakistan. Journal of Chinese Economic and Foreign Trade Studies, $11(1), 49-103$. 
Johansen, S., \& Juselius, K. (1990). Maximum likelihood estimation and inference on cointegration-with applications to the demand for money. Oxford Bulletin of Economics and Statistics, 52(2), 169-210.

Kang, S. M., Kim, M. S., \& Lee, M. (2002). The trends of composite environmental indices in Korea. Journal of Environmental Management, 64 (2), 199-206.

Kiendrebeogo, Y. (2012). The effects of financial development on trade performance and the role of institutions.

Kletzer, K., \& Bardhan, P. (1987). Credit markets and patterns of international trade. Journal of Development Economics, 27(1-2), 57-70.

La Porta, R., Lopez-de Silanes, F., \& Shleifer, A. (2002). Government ownership of banks. The Journal of Finance, 57(1), 265-301.

Levine, R. (1999). Financial development and economic growth: Views and agenda. The World Bank.

Levine, R., Loayza, N., \& Beck, T. (2000). Financial intermediation and growth: Causality and causes. Journal of Monetary Economics, 46(1), 31-77.

Manova, K. (2012). Credit constraints, heterogeneous firms, and international trade. Review of Economic Studies, 80(2), 711-744.

Ohlan, R. (2017). The relationship between tourism, financial development and economic growth in India. Future Business Journal, 3(1), 9-22.

Pearson, K. (1901). Liii. on lines and planes of closest fit to systems of points in space. The London, Edinburgh, and Dublin Philosophical Magazine and Journal of Science, 2(11), 559-572.

Persan, M., \& Pesaran, B. (1997). Microfit 4.0: Interactive econometric analysis. Oxford University Press, Oxford.

Phillips, P. C., \& Perron, P. (1988). Testing for a unit root in time series regression. Biometrika, 75(2), 335-346.

Rajan, R., \& Zingales, L. (1998). Financial development and growth. American Economic Review, 88(3), 559-586.

Rajan, R. G., \& Zingales, L. (2003). The great reversals: The politics of financial development in the twentieth century. Journal of Financial Economics, 69(1), 5-50.

Rewilak, J. (2017). The role of financial development in poverty reduction. Review of Development Finance, 7(2), 169-176.

Samba, M. C., \& Yan, Y. (2009). Financial development and international trade in manufactures: An evaluation of the relation in some selected Asian countries. International Journal of Business and Management, 4(12), 52-69.

Shahbaz, M., Van Hoang, T. H., Mahalik, M. K., \& Roubaud, D. (2017). Energy consumption, financial development and economic growth in India: New evidence from a nonlinear and asymmetric analysis. Energy Economics, 63, 199-212.

Shamim, M. A., Khan, R. A., Ghais, K. A., \& Shaikh, E. A. (2016). FDI-Export nexus in Pakistan: A time series analysis. Global Management Journal for Academic \&3 Corporate Studies, 6(1), 115-122.

Susanto, D., Rosson III, C. P., \& Costa, R. F. (2011). Financial development and international trade: Regional and sectoral analysis (Tech. Rep.). 
Svaleryd, H., \& Vlachos, J. (2005). Financial markets, the pattern of industrial specialization and comparative advantage: Evidence from OECD countries. European Economic Review, 49(1), 113-144.

Vera, K. (2010). The effect of finance system on export performance of firms (Master Thesis). Kyic School of Economics, Ukraine.

Wamboye, E., \& Mookerjee, R. (2013). Financial development and manufactured exports: The African experience. International Journal of Economic Policy in Emerging Economies, 7(1), 22-34. 